University of Nebraska - Lincoln

DigitalCommons@University of Nebraska - Lincoln

Mammalogy Papers: University of Nebraska

State Museum

Museum, University of Nebraska State

1949

\title{
The Lemming Vole, Synaptomys borealis, in Northern Minnesota
}

Ralph M. Wetzel

University of Illinois at Urbana-Champaign

Harvey L. Gunderson

University of Minnesota

Follow this and additional works at: https://digitalcommons.unl.edu/museummammalogy

Part of the Zoology Commons

Wetzel, Ralph M. and Gunderson, Harvey L., "The Lemming Vole, Synaptomys borealis, in Northern Minnesota" (1949). Mammalogy Papers: University of Nebraska State Museum. 153.

https://digitalcommons.unl.edu/museummammalogy/153

This Article is brought to you for free and open access by the Museum, University of Nebraska State at DigitalCommons@University of Nebraska - Lincoln. It has been accepted for inclusion in Mammalogy Papers: University of Nebraska State Museum by an authorized administrator of DigitalCommons@University of Nebraska Lincoln. 
THE LEMMING VOLE, SYNAPTOMYS BOREALIS, IN NORTHERN MINNESOTA

Lemming voles of the subgenus Mictomys have never been recorded from north-central United States, although they might be expected to occur there judging from records of the species Synaptomys (Mictomys) borealis from southern Manitoba. Recently, examination of specimens in the collection of the Minnesota Museum of Natural History reveals that Synaptomys borealis does occur in north-central United States for we have found the following specimens referable to that species: one immature female (No. 951, MMNH) from Williams, Lake of the Woods County, Minnesota, collected by Gustav Swanson, August 5, 1932; one adult male (No. 2552, MMNH) from Warroad, Roseau County, Minnesota, collected by H. L. Gunderson and B. J. Hayward, July 27, 1948.

These specimens are probably referable to the subspecies Synaptomys borealis smithi Anderson and Rand, which has been assigned to specimens from southern Manitoba, although comparison of body and skull measurements with published measurements proved inconclusive.-Ralph M. Werzel and Harvey L. Gunderson, Museum of Natural History, University of Illinois, Urbana, Illinois, and Museum of Natural History, University of Minnesota, Minneapolis, Minnesota. Received February 7, 1949. 